\title{
Purification and characterisation of toxin $B$ from a strain of Clostridium difficile that does not produce toxin A
}

\author{
J. F. TORRES
}

Department of Medical Microbiology, Gothenburg University, S413 46 Gothenburg, Sweden and Unidad de Investigacion en Enfermedades Infecciosas y Parasitarias, Subdireccion General Medica, Instituto Mexicano del Seguro Social, Mexico DF, Mexico

\begin{abstract}
Summary. Most toxigenic strains of Clostridium difficile produce both toxin A and toxin B. The toxin produced by $C$. difficile strain 8864 was characterised and compared with those produced by $C$. difficile strain 10463 . Toxin A was not detected by immunoassay in cultures from strain 8864 and all the cytotoxic activity produced by this strain was neutralised by antiserum to toxin B. Toxin B from strain 8864 was purified and compared with toxin B from strain 10463 . The size of the purified subunits of toxin B from strain 8864 differed slightly from those of strain 10463 and there were small immunological differences. The effect on fibroblast cells was more like that of $C$. sordellii cytotoxin than of toxin B from strain 10463. These results suggest that $C$. difficile strain 8864 produces a modified toxin B and does not produce toxin $\mathrm{A}$.
\end{abstract}

\section{Introduction}

Clostridium difficile causes pseudomembranous colitis and antibiotic-associated diarrhoea or colitis. ${ }^{1,2}$ The exotoxins produced by this micro-organism seem to be responsible for the disease. It produces at least two toxins, $\mathrm{A}$ and $\mathrm{B}$, which are high-mol.-wt proteins, sensitive to heat and highly hydrophobic. ${ }^{3,4}$ Toxin B may exist in two immunologically related molecular forms: form 1 with subunits of $230-250 \mathrm{Kda}$ and form 2 with subunits of $43 \mathrm{Kda} .{ }^{5}$ Experiments have shown that toxin A causes extensive mucosal destruction and fluid accumulation in the ileum and colon. ${ }^{6,7}$ Toxin B appears to be inactive on the intestinal mucosa ${ }^{7}$ but is highly toxic to some cells in culture. ${ }^{8}$ The morphological changes in cells are very similar to those seen with cytochalasin and seem to involve alteration of the cytoskeleton. ${ }^{9}$ Epithelial cells become rounded whereas fibroblasts become actinomorphic with contraction of the cytoplasm around the nucleus and long processes radiating from the rounded cell body. ${ }^{10}$

Almost all strains of $C$. difficile tested produce both toxins $A$ and $B$ or are non-toxigenic. ${ }^{11}$ The absence of certain amino acids seems to inhibit the production of one or the other toxin and one strain (no. 8864) produces toxin B only, even in complex media. ${ }^{12}$ In this study, the toxin produced by strain 8864 was characterised and compared with toxins produced by C. difficile strain VPI 10463.

Received 21 Feb. 1990; revised version accepted 22 Oct. 1990. Correspondence should be sent to: Dr J. F. Torres, Av. de las Aguilas 1708, Col. Loma de Guadalupe, CP 01720, Mexico DF, Mexico.

\section{Materials and methods}

\section{Bacterial strains}

C. difficile strain 8864 (CCUG 20309) was kindly provided by Dr E. Falsen, Culture Collection, University of Gothenburg, Sweden. This strain was originally isolated by Dr D. W. Burdon, Birmingham General Hospital, UK. ${ }^{12}$ Strain VPI 10463 was used for production of toxins $\mathrm{A}$ and $\mathrm{B}$.

\section{Production and purification of the toxins}

The toxins from strains 10463 and 8864 were prepared and purified as previously described. $., 13,14$ Briefly, the supernate obtained from 2-L cultures in brain heart infusion broth by centrifugation $(6000 \mathrm{rpm}, 20 \mathrm{~min})$ and membrane filtration $(0.45 \mu \mathrm{m})$ was concentrated on an XM100A ultrafiltration membrane (Amicon, USA) and washed three times with $0.1 \mathrm{M}$ Tris $(\mathrm{pH} \mathrm{8.0)}, 0.1 \mathrm{M} \mathrm{NaCl}$. The final concentrate was applied to a DEAE-Sephadex A25 (Pharmacia, Sweden) column and proteins were eluted with a $\mathrm{NaCl}$ gradient. Toxin A eluted at $0 \cdot 1-0 \cdot 2 \mathrm{M}$ and was purified by acid precipitation and by high resolution chromatography on a Mono $Q$ column (Pharmacia); final elution was done in a fast protein liquid chromatography system (FPLC, Pharmacia) with a linear gradient from 0.1 to $0.3 \mathrm{M} \mathrm{NaCl}{ }^{14}$ Toxin B was eluted from DEAE-Sephadex at $0.4 \mathrm{M}$ $\mathrm{NaCl}$ and, after concentration, was applied to a Sephacryl S400 (Pharmacia) column. Fractions with cytotoxicity were then applied to a Mono $\mathrm{Q}$ column, eluted with a gradient of $0.44-0.52 \mathrm{M} \mathrm{NaCl}^{5}$ and finally concentrated to contain about $1 \mathrm{mg}$ of protein $/ \mathrm{ml}$ and 
stored at $4^{\circ} \mathrm{C}$ for further analysis (no longer than a week).

\section{Protein assay}

Protein concentration was measured by a protein assay kit with Coomassie Brilliant Blue as the reagent (BioRad Laboratories, USA).

\section{Assay of toxins on cells}

Human lung fibroblast cells (kindly supplied by the Virology Laboratory, University of Gothenburg, Sweden) were used to measure the activity of the toxins, as described previously. ${ }^{15}$ Serial 10 -fold dilutions of the test samples were applied $(10 \mu \mathrm{l})$ to confluent cells in a 96-well microtitration plate containing $100 \mu \mathrm{l}$ of Minimal Essential Medium (Gibco, USA) in each well. Plates were examined for cell damage after $24 \mathrm{~h}$. Cytotoxic units (CU) were expressed as the maximum dilution that caused rounding of at least $50 \%$ of the cells. For neutralisation studies, samples were mixed with an equal volume of antiserum to toxin $A$ or toxin $B^{14}$ and incubated for $1 \mathrm{~h}$ before inoculation on to cells.

\section{Polyacrylamide gel electrophoresis (PAGE)}

Samples were analysed in precast gradient gels in accordance with the manufacturer's instructions (Pharmacia). Each well was loaded with 15-20 $\mu \mathrm{g}$ of protein. Non-denatured samples were run in a $4-30 \%$ gradient in $0.09 \mathrm{M}$ Tris, $0.08 \mathrm{M}$ boric acid, $0.0025 \mathrm{M}$ NaEDTA (pH 8.4) at $150 \mathrm{~V}$ for $16 \mathrm{~h}$. Some unstained gels were sliced into sections, eluted by dialysis and assayed for toxic activity. Denaturing PAGE was done in a $2-16 \%$ gradient gel in $0.04 \mathrm{M}$ Tris, $0.02 \mathrm{M}$ sodium acetate, $0.002 \mathrm{M}$ EDTA, SDS $0.2 \%$ (pH 7.4). Samples were heated at $100^{\circ} \mathrm{C}$ for $10 \mathrm{~min}$ in $0.01 \mathrm{M}$ Tris- $\mathrm{HCl}, 0.001$ м EDTA, SDS $1 \%(\mathrm{pH} 8.0)$ with or without $\beta$-mercaptoethanol $5 \%$, applied to gels and run at $300 \mathrm{~V}$ for $10 \mathrm{~min}$ and then at $150 \mathrm{~V}$ for $2 \cdot 5-3 \mathrm{~h}$. The gels were stained with Coomassie Blue R-250.

\section{Immunodiffusion}

Immunodiffusion was done in $5 \times 5 \mathrm{~cm}$ agar plates as described by Wadsworth; $;^{16} 10-20 \mu \mathrm{g}$ of antigen and undiluted antiserum were added to each well and left in a humidified chamber for $48 \mathrm{~h}$ until diffusion was complete. Plates were then washed with phosphate-buffered saline and stained with Coomassie Blue R-250. Antisera against the $230-250-\mathrm{Kda}$ and the 43-Kda subunits of toxin B molecular forms 1 and 2 respectively from $C$. difficile strain 10463 were produced in rabbits as previously described. ${ }^{5}$

\section{ELISA}

Toxin A was measured by ELISA. ${ }^{17}$ Briefly, microtitration plates (Immulon type 2; Dynatech Industries, USA) were coated with affinity purified goat antitoxin A (provided by Dr D. M. Lyerly, Anaerobe Laboratory, Virginia Polytechnic Institute and State University, Blacksburg, VA, USA) diluted 1 in 200. Bound antigen was detected with rabbit antitoxin $\mathrm{A}^{14}$ diluted 1 in 500 and horse-radish peroxidase-conjugated antirabbit immunoglobulin. Pure toxin $A$ was used as a positive control, and culture filtrates from two nontoxigenic strains of $C$. difficile as negative controls. The limit of detection of the assay was $5 \mathrm{ng} / \mathrm{ml}$.

\section{Results}

\section{Toxin production by $C$. difficule strain 8864}

The crude culture filtrate from strain 8864 contained $4.46 \times 10^{8} \mathrm{CU} / \mathrm{ml}$ (table) which was specifically neutralised by antitoxin B. No cytotoxin which could be neutralised by antitoxin A was detected in any of the fractions from DEAE-Sephadex chromatography, nor was any toxin A detected by ELISA.

\section{Purification of toxin $B$}

Toxin B eluted from DEAE-Sephadex at $0.4 \mathrm{M}$ $\mathrm{NaCl}$, with a 7.4-fold increase in specific activity and a yield of $45 \%$ (table). Gel filtration through Sephacryl S400 increased the specific activity to about 13 times with a yield of $22 \%$. The final step was FPLC on Mono Q; the cytotoxin eluted at $0.48-0.50 \mathrm{M} \mathrm{NaCl}$. The three purification steps resulted in a 25 -fold concentration of activity with an overall yield of about $8 \%$. Toxin B was purified from strain 10463 by the same scheme. Pure form 1 had a specific activity of $4.2 \times 10^{3} \mathrm{CU} / \mathrm{pg}$.

Table. Purification of the cytotoxin produced by C. difficile strain 8864

\begin{tabular}{l|cccccc}
\hline \multicolumn{1}{c|}{ Purification step } & Volume (ml) & $\begin{array}{c}\text { Protein content } \\
(\mathrm{mg} / \mathrm{ml})\end{array}$ & $\begin{array}{c}\text { Total protein } \\
(\mathrm{mg})\end{array}$ & CU/ml & Total CU & CU/pg \\
\hline Crude filtrate & 15 & 9.0 & 135 & $4.46 \times 10^{8}$ & $6.7 \times 10^{9}$ & 0.05 \\
$\begin{array}{l}0.4 \text { M DEAE- } \\
\text { Sephadex }\end{array}$ & $6 \cdot 7$ & $1 \cdot 22$ & 8.17 & $4.47 \times 10^{8}$ & $3.0 \times 10^{9}$ & 0.37 \\
Sephacryl S-400 & 3.0 & 0.77 & 2.31 & $5.00 \times 10^{8}$ & $1.5 \times 10^{9}$ & 0.65 \\
Mono' Q, FPLC & 5.5 & 0.08 & 0.44 & $1.00 \times 10^{8}$ & $5.5 \times 10^{8}$ & 1.25 \\
\hline
\end{tabular}




\section{$P A G E$}

Under non-denaturing conditions, cytotoxin from strain 8864 migrated in two bands (fig. 1a, lane 1), one migrating slightly faster than toxin $B$ form 1 of strain 10463 (lane 2), and the other similar to toxin B form 2 from strain 10463 (lane 3). Cytotoxic activity was eluted from both bands; the third faint band had no cytotoxic activity. Results of SDS-PAGE are shown in fig. $1 \mathrm{~b}$. In the absence of reducing agents, the cytotoxin of strain 8864 appeared as two bands of about $220 \mathrm{Kda}$ and $105 \mathrm{Kda}$ respectively (lane 1). The 220-Kda subunit migrated slightly faster than the subunit from toxin B form 1 of strain 10463 (230$250 \mathrm{Kda}$, lane 3) whereas the $105-\mathrm{Kda}$ subunit was similar to the subunit of toxin B form 2 from strain 10463 (not shown). There was no change in the 220$\mathrm{Kda}$ band after treatment with a reducing agent

a

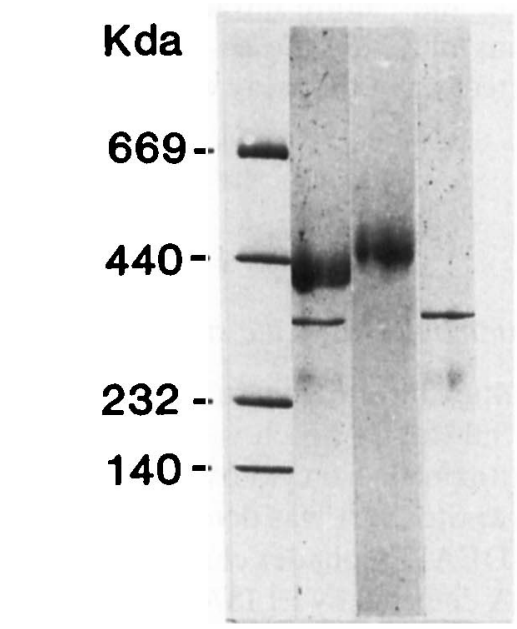

b

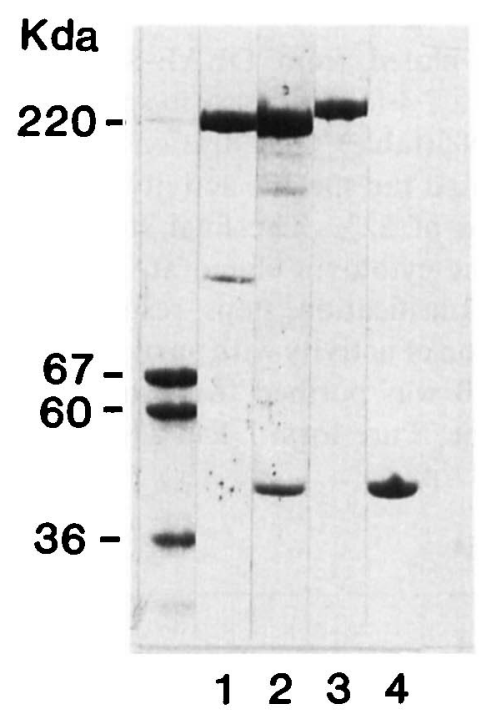

Fig. 1. PAGE of the purified cytotoxins from $C$. difficile strains 8864 and 10463. (a) PAGE in non-denaturing conditions: lane 1, cytotoxin from strain $8864 ; 2$ and 3 , toxin B from strain 10463 , molecular forms 1 and 2 respectively. (b) SDS-PAGE; lanes 1 and 2 , cytotoxin from strain 8864 , without and with $\beta$-mercaptoethanol respectively; 3 and 4 , toxin $B$ molecular forms 1 and 2 respectively from $C$. difficile strain 10463 treated with $\beta$-mercaptoethanol. (lane 2) whereas the 105-Kda subunit dissociated into peptides of about $43 \mathrm{Kda}$ (lane 2), similar to those formed after reducing toxin B form 2 of strain 10463 (lane 4).

\section{Immunodiffusion}

The two precipitin lines formed between toxin B form 2 of $C$. difficile strain 10463 and its own antiserum fused in identity with the single precipitin formed with toxin B form 1 (fig. 2a) as previously described. ${ }^{5}$ Cytotoxin $B$ from strain 8864 formed a single precipitin line with antiserum to toxin B form 1 of strain 10463, which showed partial identity with the precipitin formed with toxin B form 1 of strain 10463 (fig. 2b); cytotoxin from strain 8864 formed two precipitin lines with antiserum to toxin B form 2 of strain 10463, which showed identity with one of the precipitin lines formed with purified toxin B form 2 from strain 10463 (fig. 2b).

\section{Cytotoxic effects on lung fibroblast}

In fig. 3, the cytotoxic effect of purified toxin B from C. difficile strain 8864 is compared with that of toxin B molecular form 1 from $C$. difficile strain $10463 ; 8 \times 10^{4}$ CU of toxin B form 1 of strain 10463 rounded the cells and many of them showed actinomorphic changes
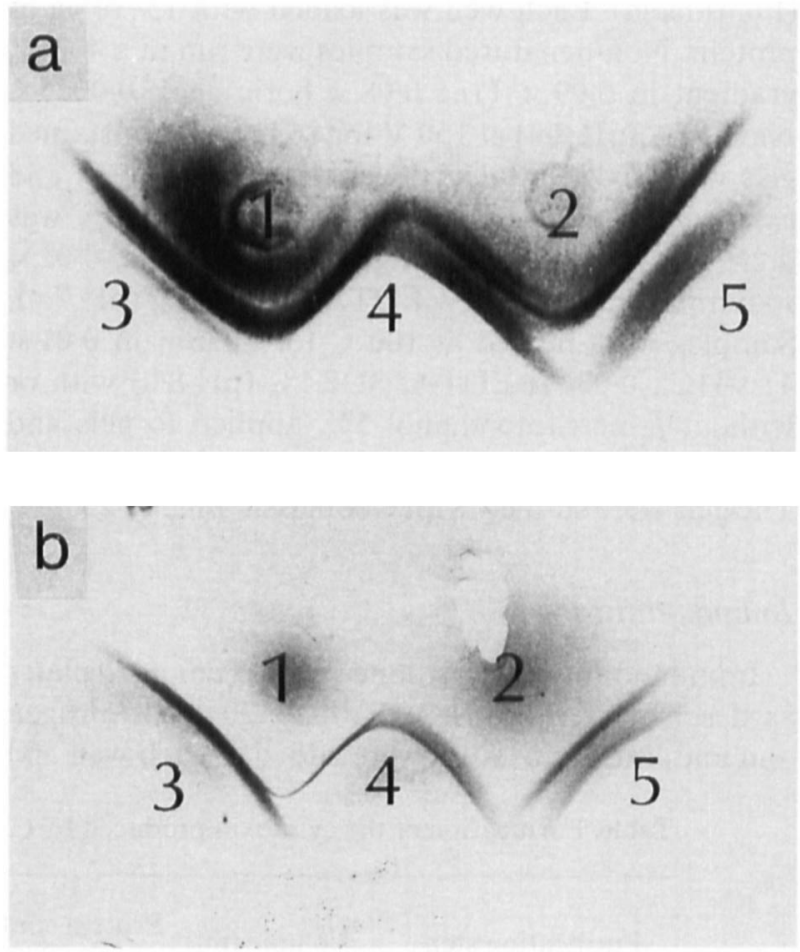

Fig. 2. Immunodiffusion test. (a) Well 1, antiserum to $C$. difficile strain 10463 toxin B molecular form $1 ; 2$, antiserum to $C$. difficile strain 10463 toxin B molecular form 2; 3, pure 10463-toxin B molecular form $1 ; 4$ and 5, pure 10463-toxin B molecular form 2. (b) Well 1, antiserum to strain 10463 toxin B molecular form 1; 2, antiserum to strain 10463 toxin $B$ molecular form $2 ; 3$, pure 10463 toxin B molecular form 1; 4, strain 8864-cytotoxin; 5 , pure 10463 toxin B molecular form 2. 

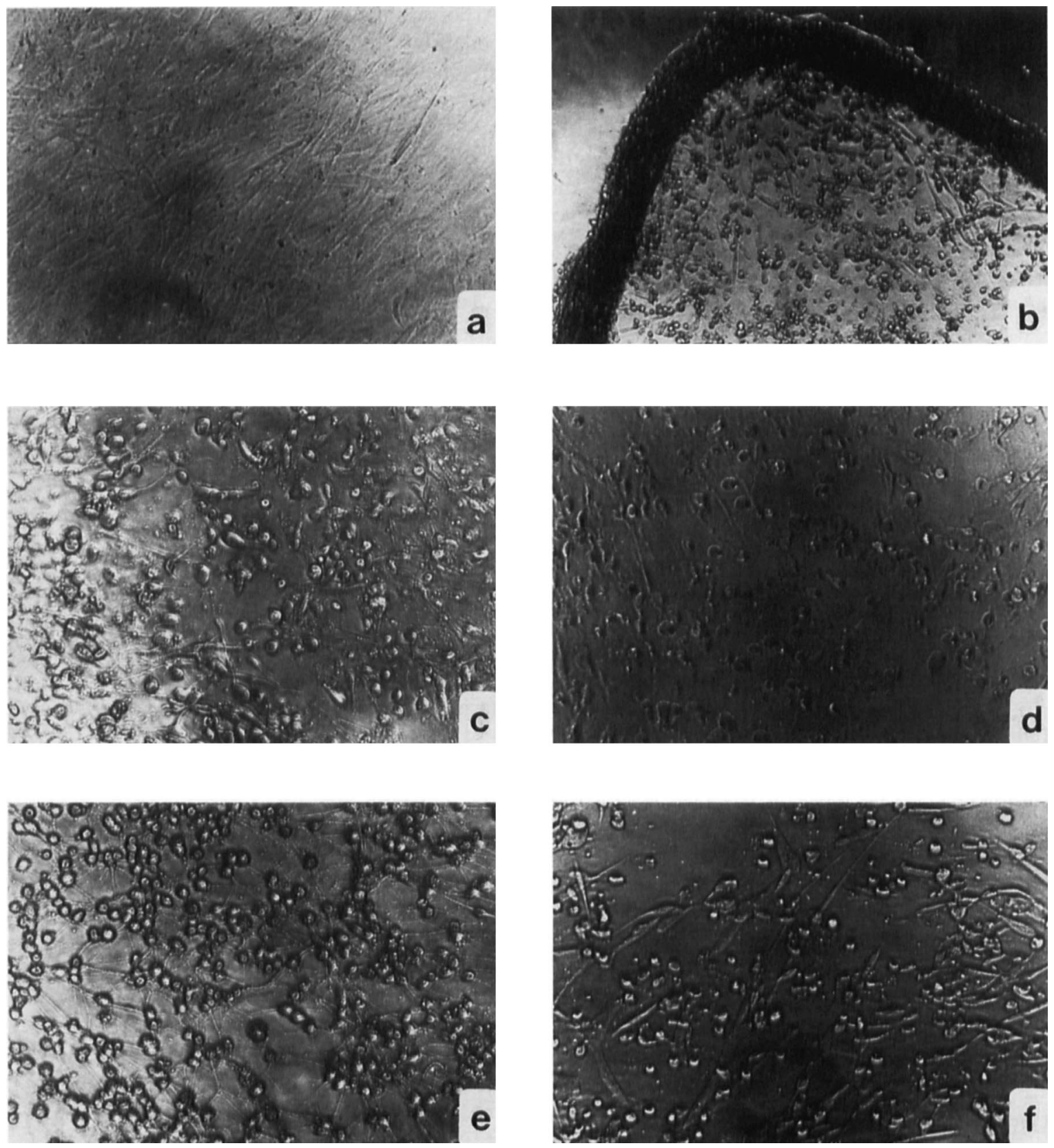

Fig. 3. Effect of cytotoxin from C. difficile strain 8864 and toxin B molecular form 1 from $C$. difficile strain 10463 on human lung fibroblast cells: (a) untreated cells; (b), (d) and (f) cells incubated with cytotoxin from strain 8864 , (b) $1 \times 10^{4} \mathrm{CU}(\times 50),(d) 1 \times 10^{3} \mathrm{CU}(\times 100)$ and (f) $1 \times 10^{2} \mathrm{CU}(\times 100)$; (c) and (e), cells treated with toxin B molecular form 1 from strain $10463(\times 100):(\mathrm{c}) 8 \times 10^{4} \mathrm{CU}$ and $(\mathrm{e}) 8 \times 10^{2} \mathrm{CU}$.

(fig. 3c), whereas with $8 \times 10^{2} \mathrm{CU}$ all the cells became actinomorphic (fig. 3e). Although $8000 \mathrm{pg}\left(1 \times 10^{4}\right.$ $\mathrm{CU})$ of cytotoxin $\mathrm{B}$ from strain 8864 caused extensive detachment of cells (fig. 3b), $8000 \mathrm{pg}\left(3 \times 10^{7} \mathrm{CU}\right)$ of toxin B form 1 from strain 10463 did not cause detachment of the cells; $1 \times 10^{3} \mathrm{CU}$ of toxin from strain 8864 rounded the cells (fig. 3d) and $1 \times 10^{2} \mathrm{CU}$ caused rounding and elongation of the cells. Actinomorphic changes were not seen (fig. 3f).

\section{Discussion}

It is thought that the production of toxins A and B by $C$. difficile is co-regulated ${ }^{11}$ because most strains which have been described produce both toxins or are non-toxigenic. However, C. difficile strain 8864 appears to produce toxin B only. Although this strain was grown under optimal conditions for toxin production, ${ }^{18-20}$ its cytotoxic activity was completely neutralised by antitoxin $B$, whereas antitoxin $A$ had no effect. Furthermore, no toxin A activity was detected during the purification procedures or by ELISA. These results strongly suggest that $C$. difficile strain 8864 does not produce toxin A even in an inactive form.

Analysis of toxin B from strain 8864 in SDS-PAGE after treatment with $\beta$-mercaptoethanol demonstrated two subunits of $220 \mathrm{Kda}$ and $43 \mathrm{Kda}$ whereas toxin B from strain 10463 had subunits of $230-250 \mathrm{Kda}$ (form 1) or $43 \mathrm{Kda}$ (form 2). In gel immunodiffusion, 
the cytotoxin from strain 8864 showed partial identity with the 230-Kda subunit of toxin B from strain 10463 indicating that it lacked some toxin B epitopes; these missing epitopes might be responsible for the difference in size observed in PAGE.

The effect on fibroblast cells was also different; with toxin B from strain 10463, cells became rounded and highly arborised, giving the characteristic actinomorphic appearance. In contrast, with the toxin B from strain 8864, no arborisation of cells occurred but there was rounding and significant detachment.

\section{References}

1. Bartlett JG. Antibiotic-associated pseudomembranous colitis Rev Infect Dis 1979; 1: 530-539.

2. Gerding DN, Olson MM, Peterson LR et al. Clostridium difficile-associated diarrhea and colitis in adults. Arch Intern Med 1986; 146: 95-100.

3. Banno $Y$, Kobayashi $T$, Kono $H$, Watanabe $K$, Ueno $K$ Nozawa $Y$. Biochemical characterisation and biologic actions of two toxins (D-1 and D-2) from Clostridium difficile. Rev Infect Dis 1984; 6: Suppl: S11-S20.

4. Lyerly DM, Roberts MD, Phelps CJ, Wilkins TD. Purification and properties of toxin A and toxin B of Clostridium difficile. FEMS Microbiol Lett 1986; 33: 31-35.

5. Torres JF, Lönnroth I. Purification and characterisation of two forms of toxin B produced by Clostridium difficile. FEBS Lett 1988 ; 233 : 417-420.

6. Mitchell TJ, Ketley JM, Haslam SC et al. Effect of toxin A and B of Clostridium difficile on rabbit ileum and colon. Gut $1986 ; 27: 78-85$

7. Triadafilopoulos G, Pothoulakis C, O'Brien MJ, LaMont JT. Differential effects of Clostridium difficile toxins A and B on rabbit ileum. Gastroenterology 1987; 93: 273-279.

8. Lima AAM, Lyerly DM, Wilkins TD, Innes DJ, Guerrant RL. Effects of Clostridium difficile toxins $\mathrm{A}$ and $\mathrm{B}$ in rabbit small and large intestine in vivo and on cultured cells in vitro. Infect Immun 1988; 56: 582-588.

9. Wedel N, Toselli P, Pothoulakis C et al. Ultrastructural effects of Clostridium difficile toxin $B$ on smooth muscle cells and fibroblasts. Exp Cell Res 1983; 148: 413-422.

10. Thelestam M, Florin I. Cytopathogenic action of Clostridium difficile toxins. J Toxicol Tox Rev 1984; 3: 139-180.

11. Lyerly DM, Krivan HC, Wilkins TD. Clostridium difficile: its disease and toxins. Clin Microbiol Rev 1988; 1 : 1-18.
Arborisation seemed to occur because the cytoplasm collapsed around the nucleus and projections remained attached to the supporting matrix by the adhesion plaque proteins. ${ }^{21}$ The cytotoxin from strain 8864 may have an effect on vinculin or talin or on related components of the adhesion plaque proteins. C. sordelli toxin also causes rounding of fibroblast cells without arborisation. ${ }^{22}$

I thank I. Lonnroth for his critical review of the manuscript.

12. Haslam SC, Ketley JM, Mitchell TJ, Stephen J, Burdon DW, Candy DCA. Growth of Clostridium difficile and production of toxins A and B in complex and defined media. $J \mathrm{Med}$ Microbiol 1986; 21: 293-297.

13. Taylor NS, Thorne GM, Bartlett JG. Comparison of two toxins produced by Clostridium difficile. Infect Immun 1981; 34 $1036 \div 1043$.

14. Torres JF, Lönnroth I. Production, purification and characterization of Clostridium difficile toxic proteins different from toxin A and from toxin B. Biochim Biophys Acta 1989; 998 : 151-157.

15. Chang T-W, Lauermann M, Bartlett JG. Cytotoxicity assay in antibiotic-associated colitis. J Infect Dis 1979; 140: 765 770.

16. Wadsworth C. A slide microtechnique for the analysis of immune precipitates in gel. Int Arch Allergy Appl Immunol $1957 ; 10: 355-360$.

17. Lyerly DM, Sullivan NM, Wilkins TD. Enzyme-linked immunosorbent assay for Clostridium difficile toxin A. J Clin Microbiol 1983; 17: 72-78

18. Rolfe RD, Finegold SM. Purification and characterization of Clostridium difficile toxin. Infect Immun 1979; 25: 191-201.

19. Lyerly DM, Wilkins TD. Characteristics of the toxins of Clostridium difficile. In: Borriello SP (ed) Antibiotic associated diarrhoea and colitis. (Developments in gastroenterology 5.) Boston MA, Nijhoff. 1984: 89.

20. Torres JF, Lönnroth I. Comparison of methods for the production and purification of toxin A from Clostridium difficile. FEMS Microbiol Lett 1988; 52: 41-45.

21. Ottlinger $\mathrm{ME}$, Lin S. Clostridium difficile toxin B induces reorganization of actin, vinculin, and talin in cultured cells. Exp Cell Res 1988; 174: 215-229.

22. Popoff MR. Purification and characterization of Clostridium sordellii lethal toxin and cross-reactivity with Clostridium difficile cytotoxin. Infect Immun 1987; 55: 35-43. 